\title{
50. A REVIEW AND COMPARISON OF CARBONATE ROCK MAGNETIZATION: LEG 133, QUEENSLAND PLATEAU, AUSTRALIA ${ }^{1}$
}

\author{
Donald F. McNeill ${ }^{2}$
}

\begin{abstract}
A review and summary of carbonate rock magnetics from Leg 133 sites on the Queensland Plateau and comparison with other pure carbonates of similar age are presented to assess the nature and variation of magnetization in large carbonate platforms. A combination of rock-magnetic techniques suggests that the primary carrier of magnetic remanence is ultrafine-grained, singledomain crystals of either magnetite or maghemite. Rock-magnetic, geochemical, and demagnetization results suggest that much of the original magnetite has been oxidized to maghemite and may have been further altered to a "soft" oxyhydroxide phase. A transition to improved preservation of magnetic remanence is coincident with subsidence of the platform and a shift from neritic to bathyal conditions. Comparison with rock-magnetic characteristics from shallow Bahamian platforms confirms a similar source of magnetization, probably biogenic. Variation in the preservation of remanence is perhaps related to local fluid flow and geohistory of the platforms.
\end{abstract}

\section{INTRODUCTION}

During the past decade, the development of superconducting rock magnetometers (Fuller et al., 1985) having low background sensitivity has enabled the investigation, characterization, and application of carbonate paleomagnetism. First, carbonate rocks were generally thought to be too weakly magnetized for paleomagnetic and magnetostratigraphic purposes. Cryogenic magnetometers housed in low magnetic field environments have been successful for expanding the application of paleomagnetism to carbonate sediments and rocks, especially shallow platform carbonates, periplatform carbonates, and deep-water carbonates. Second, the realization that low-temperature, biogenic magnetite could provide an in-situ source of magnetic remanence (Kirschvink, 1983; Kirschvink and Chang, 1984) provided new potential for paleomagnetism and magnetostratigraphy in areas isolated from direct detrital influx.

With this expansion of carbonate magnetostratigraphy, the need arose to understand completely the nature of magnetic remanence, the source of magnetic grains, post-depositional factors (compaction, cementation, neomorphism) that affect directional data, and the susceptibility of this remanence to destruction, alteration, and remagnetization. Remanence characterization is important for assessing the primary vs. secondary nature of carbonate remanence and its resulting directional data. Thus, carbonate rock-magnetic studies provide an important confirmation, and mode for comparison, for the primary or secondary origins of the magnetic remanence. In addition, identification of distinct characteristics of either primary or secondary magnetization helps considerably in the confirmation and interpretation of remanence associated with ancient, shallow-water Paleozoic carbonates.

The primary objective of this study is to provide a concise summary of the rock-magnetic characteristics of relatively pure carbonates cored during Leg 133 on the Queensland Plateau. Second, a general comparison to rock-magnetic characteristics from other shallow-water carbonates from similar settings is included. Much of the detailed information and data summarized here can be found in the chapter and appendixes of McNeill et al. (this volume). Additional information about rock magnetization in shallow-water and slope

\footnotetext{
' McKenzie, J.A., Davies, P.J., Palmer-Julson, A., et al., 1993.Proc. ODP, Sci. Results, 133: College Station, TX (Ocean Drilling Program).

${ }^{2}$ Division of Marine Geology and Geophysics, Rosenstiel School of Marine and Atmospheric Science, University of Miami, 4600 Rickenbacker Cswy., Miami, FL 33149 1098, U.S.A.
}

carbonates can be found in McNeill (1989; 1990), Aïssaoui et al. (1990), and McNeill and Kirschvink (in press).

\section{METHODS}

All rock-magnetic analyses on which this summary is based were conducted at either the California Institute of Technology, using a $2 \mathrm{G}$ Enterprises 760 superconducting magnetometer, or at the Rosenstiel School of Marine and Atmospheric Science, University of Miami, using a $2 \mathrm{G}$ Enterprises 755 magnetometer.

Adetailed summary of paleomagnetic and rock-magnetic methods can be found in McNeill et al. (this volume). Procedures included (1) coercivity spectral analysis with isothermal remanent magnetization (IRM) saturation and alternating field (AF) demagnetization of IRM; (2) anhysteretic remanent magnetization (ARM) acquisition at 100 $\mathrm{mT}$ with field biases of $0,0.5,1.0,1.5$, and $2.0 \mathrm{mT}$, and AF demagnetization of ARM, which permits the modified Lowrie-Fuller test (Lowrie and Fuller, 1971) to be performed; and (3) ARM acquisition test (Cisowski, 1981), which consisted of ARM data at each field bias step vs. the ratio of ARM to maximum IRM value (often the saturation IRM value). The ARM plot was calibrated against magnetically noninteracting bacterial magnetite and highly interacting single-domain chiton magnetite.

Magnetic grains contained within the carbonate were separated using the technique of Chang and Kirschvink (1985). The magnetic separates were examined under a Phillips 300 transmission electron microscope (TEM) at $100 \mathrm{kV}$ to identify grain dimensions and crystal morphology.

Carbonate demagnetization characteristics were compiled from $\mathrm{AF}$ demagnetization in progressively higher alternating fields, usually at steps of 5 or $10 \mathrm{mT}$. Maximum AF fields needed to demagnetize the carbonates are summarized in McNeill et al.'s appendix (this volume).

Iron geochemistry results are shown in McNeill et al. (this volume), and analytical procedures followed are those of Leslie et al. (1990).

\section{RESULTS AND DISCUSSION}

\section{Carbonate Rock Magnetics: Queensland Plateau}

\section{Magnetic Intensity}

Volume-normalized natural remanent magnetization (NRM) and AF magnetic moments in the Queensland Plateau sites (811 through $814,818,825)$ exhibited a wide range of values, with generally higher values $\left(>5 \times 10^{-7} \mathrm{Am}^{2} / \mathrm{kg}\right)$ in the upper portion, and lower values $(<5$ $\times 10^{-7} \mathrm{Am}^{2} / \mathrm{kg}$ ) in the lower portion of the core. The downward 
decrease in magnetic intensity was usually transitional over a 10- to 20-m-thick zone. Hole $818 \mathrm{~B}$, on the deep margin of the plateau, exhibited extremely weak intensities throughout most of the hole and did not exhibit the common near-surface high in magnetic intensity. In terms of the age of remanence decrease, the sediment containing this decrease is within an age range of 2.5 to $3.5 \mathrm{Ma}$, based on calcareous nannofossil and foraminifer biostratigraphy.

The demagnetization trend of typical carbonates from Holes 813A and $814 \mathrm{~A}$ shows relatively good response to $\mathrm{AF}$ demagnetization (see Fig. 6, McNeill et al., this volume). In most cases, the sample's moment decays uniformly with higher AF fields. Median destructive field (MDF) values for samples in the lower, weaker remanence portion of the cores in general are lower than the upper portion (Fig. 1).

\section{Source of Magnetic Remanence}

Coercivity spectral analysis indicates that the primary source of magnetic remanence is held by either single-domain magnetite or maghemite, with perhaps a superparamagnetic component. For most platform carbonates, the coercivity spectra show saturation at approximately $100 \mathrm{mT}$, with the intersection at approximately 40 to $50 \mathrm{mT}$. A single-domain component is supported by the similarity of saturation magnetization and saturation remanent magnetization values to known single-domain magnetite/maghemite-bearing carbonates (see Table 2, McNeill et al., this volume). The nature of the IRM saturation curve and the AF demagnetization curves from the coercivity spectra is notably similar to carbonates having a single-domain remanence with a superparamagnetic component (Chang et al., 1987; Stolz et al., 1986). Coercivity values (21-31 mT; see Table 2, McNeill et al., this volume) are consistent with carbonates known to carry a magnetite/maghemite remanence. In addition, the modified Lowrie-Fuller test also supports a single-domain or pseudo single-domain magnetization in sites near the platform top (811 through 814$)$. Two deep-water slope sites $(817$ and 818) had samples that failed the modified Lowrie-Fuller test, which suggests a dominantly multidomain magnetic remanence. However, the relatively weak remanence at these two sites suggests that the magnetic component is extremely minor.

The TEM observations further support a single-domain grain size for magnetite or maghemite, with grains in the range of 0.06 to 0.1 $\mu \mathrm{m}$ (Butler and Banerjee, 1975). Crystal dimensions measured from TEM photomicrographs are within the known range of single-domain magnetite of biogenic origin (Fig. 2). In the TEM, the grains often show nonuniform electron densities, poorly defined crystal boundaries, and give the appearance of partial grain corrosion. Furthermore, a distinct difference in the preservation status of magnetic crystals occurs between the zone of relatively high (upper) and low (lower) magnetic intensity, with grain degradation in the lower zone. These grains may have been partially or fully oxidized to maghemite. Lowtemperature remanence analyses in similar carbonate rocks from the Bahamas indicates that at least a partial maghemite mineralogy is present. The coercivity spectrum of Queensland Plateau carbonates indicate that the magnetic grains have probably undergone some degree of oxidation (to maghemite?) because the slope of the IRM saturation curve is considerably more gradual than that found in pure single-domain magnetite samples. The AF demagnetization of IRM is also more gradual than abrupt, as is characteristic of magnetostatically interacting single-domain magnetite/maghemite.

\section{ARM Acquisition and Post-depositional Modification}

ARM acquisition results throughout the cored interval show a transition with depth from more noninteracting grain configurations to a more highly interacting configuration. Relative magnetostatic interaction is assessed through comparison between the noninteractive single-domain particles obtained from Aquaspirillum magnetotacticum bacteria (upper open circles in Fig. 3) and fully interactive
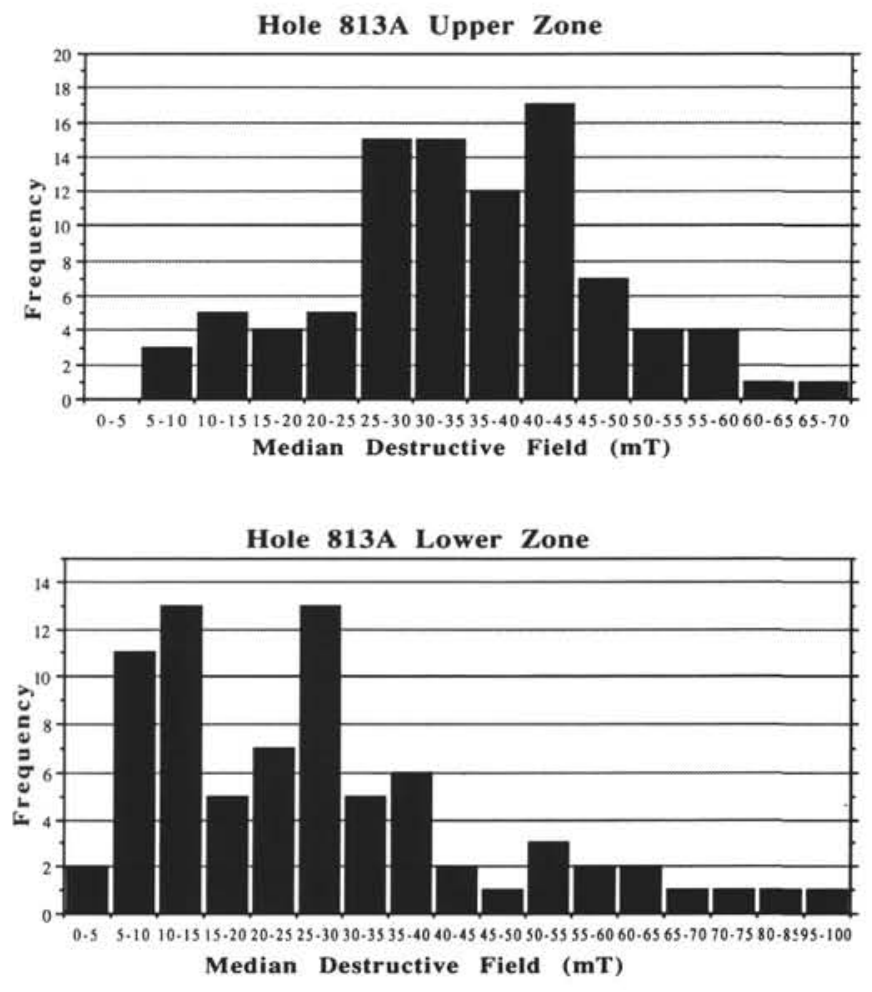

Figure 1. Histogram of median destructive field values in Hole 813A, representative of samples in the shallow, upper high-remanence zone and the deeper, low-remanence zone seen in cores from Queensland Plateau. These values probably reflect differences in preservation related to platform subsidence.

single-domain particles from chiton teeth (lower open circles in Fig. 3). Single crystals or linear chains gain a stronger ARM in weakly biasing fields, and a weak ARM is acquired by highly interacting grain aggregates. This transition to a more interacting status with depth may be related to progressive lithification (Fig. 3). In general, the near-surface sediments and unconsolidated oozes show the most noninteracting grain configuration, which consists of either aligned chains or single crystals. The more cemented chalk (and limestone) zones show an abrupt move toward more magnetically interacting grain configurations. One working hypothesis proposes that progressive growth of cement crystals in the carbonate matrix may alter the magnetic crystal chains that result from a biogenic source. As the chains are altered, they move toward grain clusters and a more magnetostatic interacting geometry.

\section{Remanence Alteration and Destruction?}

The distinct decrease in remanence with depth in several of the Queensland Plateau sites can be attributed to either a change in the amount and source of magnetic minerals or a depth/age destruction phenomenon. Although no direct evidence was found for the destruction of magnetite, several lines of evidence suggest an oxidation to maghemite from an original magnetite mineralogy. Geochemically, the downcore increase in ferric iron supports the formation of a ferric oxyhydroxide phase, assuming the absence of any silicate minerals that could provide adsorbed $\mathrm{Fe}^{+2}$ and $\mathrm{Fe}^{+3}$. Second, the crystalline ferric oxides decrease downcore, which further supports a ferric oxyhydroxide phase at the expense of a ferric oxide phase(s). This relatively "soft" phase may have resulted from the alteration of maghemite, which was perhaps an oxidation product of the original magnetite. The rapid movement of seawater through the platform, as evidenced from shipboard geochemical pore water profiles (Shipboard Scientific Party, 1991) and post-cruise study (Elderfield et al., this volume), probably contributed to these reactions. 


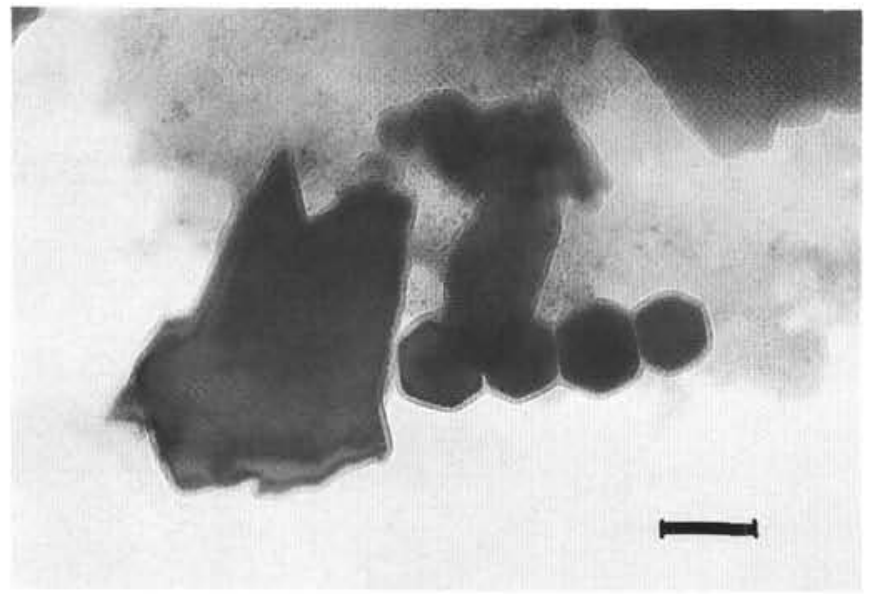

Figure 2. TEM photomicrograph of ultrafine-grained magnetic crystals. Crystal dimensions are within the known range of single-domain magnetite. Scale bar $=0.1 \mu \mathrm{m}$.

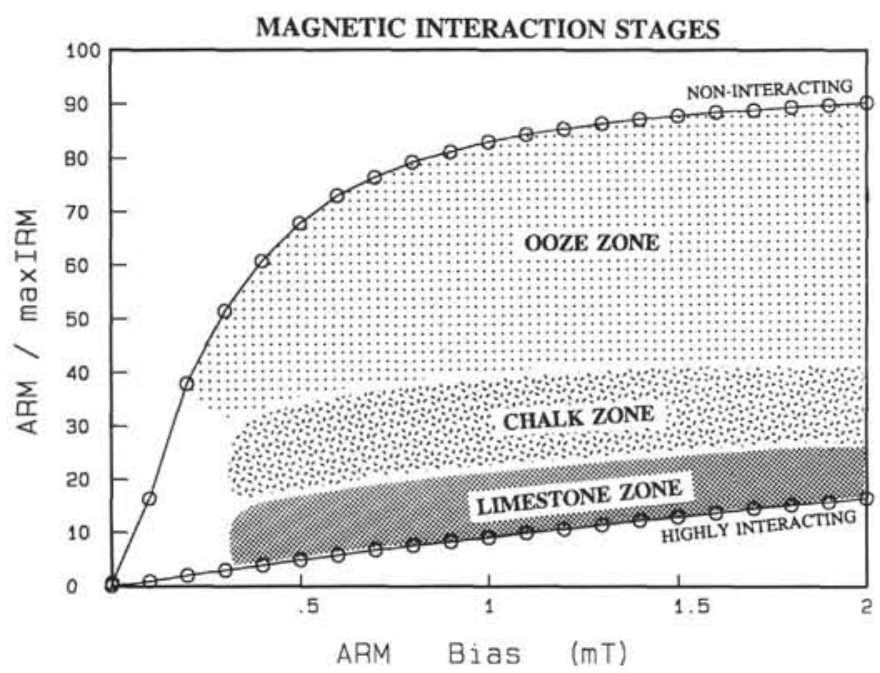

Figure 3. General zones of ooze-chalk-limestone measured from Leg 133 carbonate samples. Most samples were ooze and chalk. At this point, the limestone zone is poorly defined for Queensland Plateau samples. The transition to more magnetostatic interactive status suggests that volume reduction and cementation influence configuration of the magnetic particles.

\section{Comparison of Rock Magnetism to Other Late Cenozoic Carbonates}

Magnetization in Queensland Plateau carbonates is similar to other shallow-water and slope carbonates characterized from the Bahamas. The most significant difference is in the weaker and unstable nature of remanence below the top 10 to $25 \mathrm{mbsf}$. Compared to other carbonates at the NRM level (Fig. 4), the general range of intensity values is similar to, albeit slightly weaker than, other carbonates of similar age. Upon AF demagnetization, the Queensland Plateau sediments decay rapidly in low-to-moderate fields (Fig. 5). Bahamian platform carbonates have slightly higher NRM intensities and appear to be considerably "harder" in their response to AF demagnetization. As expected, the dominant single-domain magnetite mineralogy shows limited response to $\mathrm{AF}$ demagnetization. In most cases, low field $\mathrm{AF}$ is used to remove any "soft" component of magnetization that may reside in minor maghemite oxidation or extremely small grains near the single-domain/ superparamagnetic boundary.

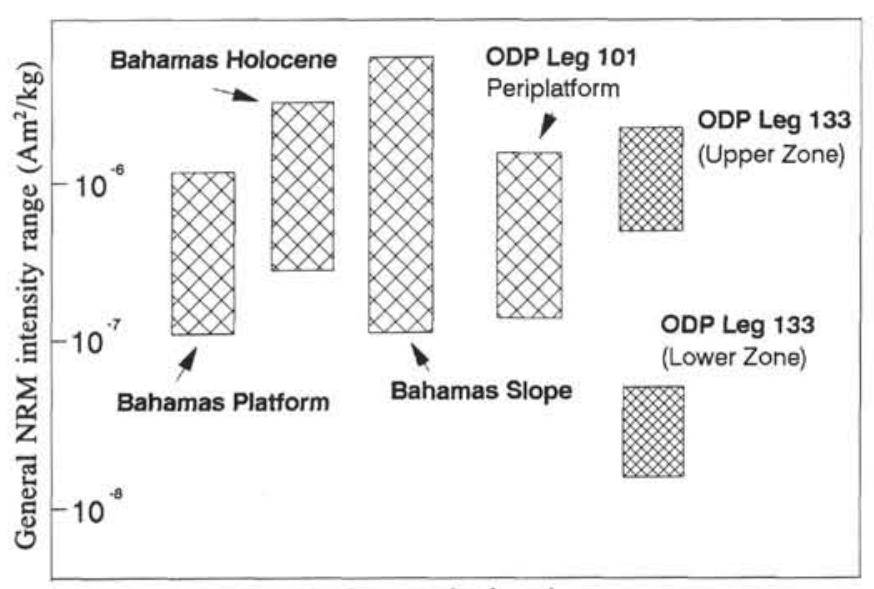

Carbonate site location

Figure 4. Generalized range summary of NRM intensities measured from various carbonate sediments. Note the relatively weak intensity found in the lower portion of the Queensland Plateau sites. Bahamian shallow-water carbonates are also weakly magnetized, but exhibit resistance to $\mathrm{AF}$ demagnetization and require thermal demagnetization from $350^{\circ}$ to $500^{\circ} \mathrm{C}$.

In both the Queensland Plateau and the Bahamas platforms, the relatively pure nature of the carbonates (extremely minor detrital magnetic influx) suggests an in-situ source for the ultrafine magnetic component. Biogenic magnetite has been shown to be a widespread component of many modern carbonate environments in the Bahamas (McNeill, 1990), and as the primary carrier of magnetic remanence in the subsurface (McNeill et al., 1988). TEM examination of crystals showing morphologies (chains) and dimensions within the range of known bacterial generated magnetite (McNeill et al., 1988) strongly supports a biogenic origin for the Queensland Plateau carbonates. In addition, coercivity and ARM characterization of sediments within the top few meters below the sea floor (Fig. 6) are remarkably similar to those from pure, cultured magnetotactic bacteria. These results suggest that magnetic bacteria contribute to the magnetic remanence of the sediments and, based on their widespread occurrence, it is assumed that they were present throughout deposition on the plateau.

The preservation of ultrafine-grained magnetite/maghemite is critical for use in paleomagnetic analyses and magnetostratigraphic dating of carbonates. On the Queensland Plateau, changes in magnetic remanence may involve either a source area/influx change or destruction through pore water-controlled diagenetic reactions, or both. The subsidence of the platform (Shipboard Scientific Party, 1991) and resulting change in depositional environment (i.e., neritic to upper bathyal) may also have influenced the preservation status of the magnetic remanence. It appears that in the case of Sites 812 through 814 , the upward increase in remanence is associated with the platform subsidence, based on the core depth of neritic to upper bathyal transition and the depth of the intensity transition zone (Table 1). If this is the case, and the nature of magnetic remanence is the same, this would argue for a depositionally influenced diagenetic control on magnetization, with conditions during neritic deposition less favorable to long-term remanence preservation.

ARM acquisition experiments that suggest cementation influences the magnetic grain configuration are consistent with recent work in shallow-water carbonates (McNeill et al., 1991) that shows initial dewatering and bioturbation to have minimal, if any, effect on magnetostatic grain interaction or grain clustering. In this study of Bahamian platform sediments, McNeill et al. examined 1- to 2-mlong, shallow cores in Holocene sediments and found that the carbonate sediments retained a highly noninteracting status through initial burial, sediment dewatering, and moderate-to-intense bioturbation. If these results can be extrapolated to other carbonate environments, 

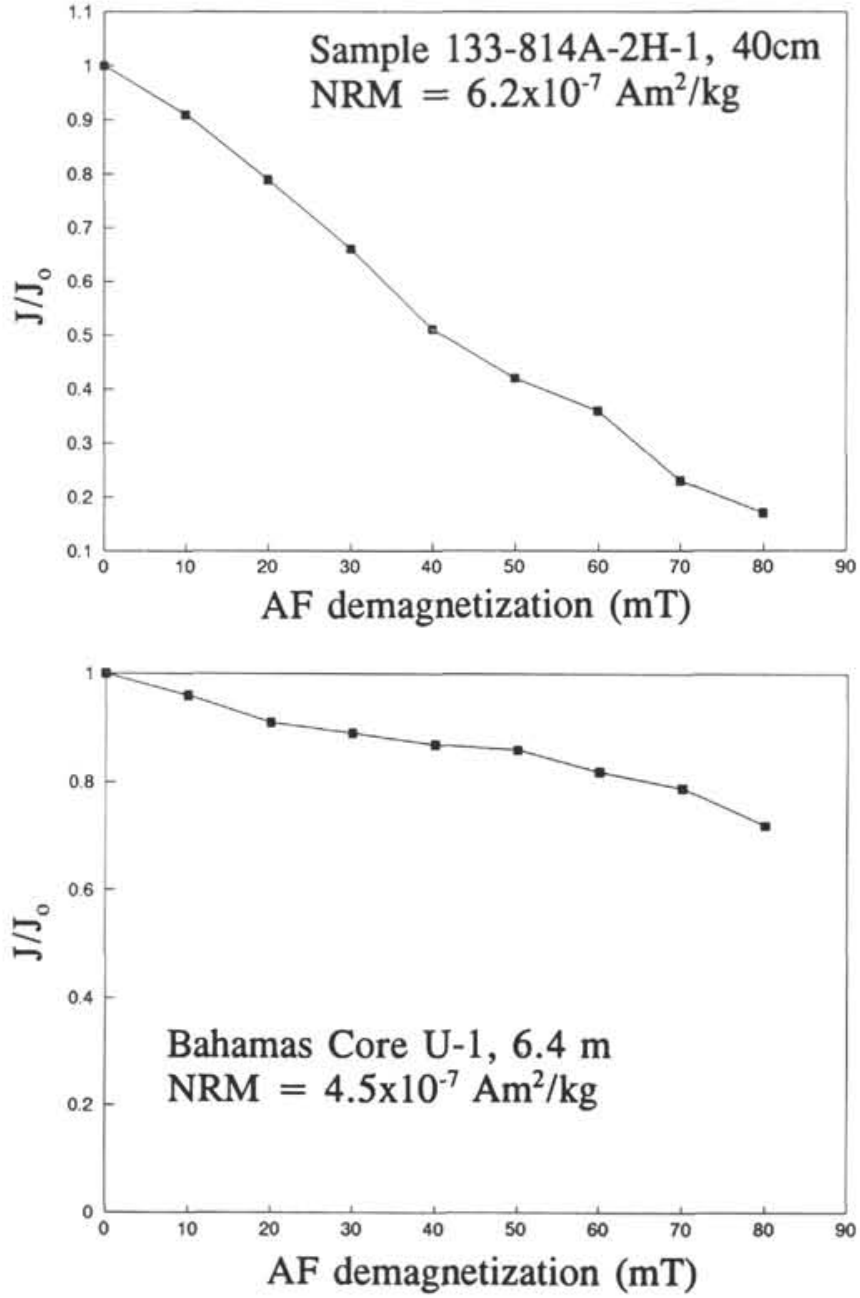

Figure $5 . J / J_{0}$ plots for a typical sample from in the upper higher intensity portion of Hole 814A and from a Pleistocene shallow platform facies in a core from Great Bahama Bank (U-1). The Queensland Plateau samples respond to progressive AF demagnetization, whereas the Bahamian sample tends to have an initial decay at low AF fields ( $15 \mathrm{mT}$ ), and then shows little subsequent decay with higher AF fields.

they would tend to constrain the transition from chainlike, noninteracting status to a more interacting grain-cluster status through mechanical means associated with precipitation of carbonate cements (Fig. 7). This physical breakage(?) of crystal chains likely occurs with both marine and meteoric cementation.

\section{Carbonate Platform Magnetization}

Magnetic remanence and the preservation of magnetic polarity in shallow-water carbonates appears to be highly variable in the relatively few examples that have so far been studied in necessary detail. The two components necessary for magnetization in isolated platform settings include (1) a source of nondetrital magnetic material as well as (2) subsequent preservation of those magnetic minerals. Within the Queensland Plateau, the recovered neritic facies has undergone considerable destruction of depositional or early post-depositional remanence. Whereas in the Bahamas, the shallow-water facies retain a much stronger remanence as well as reliable directional data (McNeill, 1989) in approximately $80 \%$ of the more than 1300 platform samples measured. A significant difference in the history and regional setting of the two platforms must be invoked to explain the discrepancies in mag-
Table 1. Comparison of magnetic intensity decrease and transition from shallow-to deep-water deposition, Queensland Plateau.

\begin{tabular}{lcc}
\hline Hole & $\begin{array}{c}\text { Depth to intensity } \\
\text { decrease (mbsf) }\end{array}$ & $\begin{array}{c}\text { Neritic/upper bathyal } \\
\text { transition (mbsf) }\end{array}$ \\
\hline $813 \mathrm{~A}$ & $\begin{array}{l}13 \text { (transition 2) } \\
85 \text { (transition 1) } \\
30\end{array}$ & $75-80$ \\
$812 \mathrm{~A}, 812 \mathrm{C}$ & $50-60$ & 28 \\
$814 \mathrm{~A}$ & $\begin{array}{c}30 \\
8\end{array}$ & $45-60$ \\
\hline
\end{tabular}

${ }^{\mathrm{a}}$ From Table 1, McNeill et al. (this volume).

b From Shipboard Scientific Party (1991).
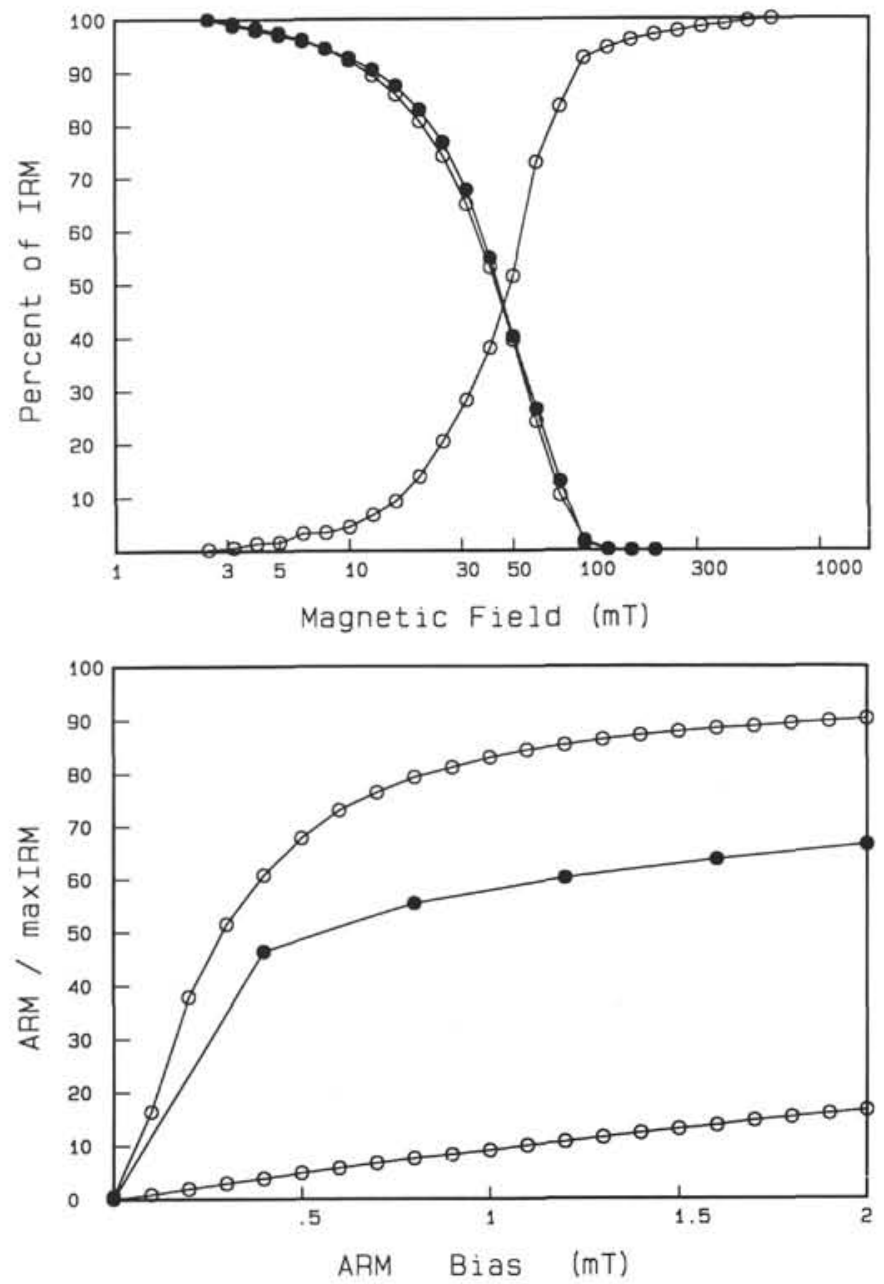

Figure 6. Coercivity spectral analysis and ARM acquisition results from near the very top of Sample 133-812C-1H-1, 6-8 cm. These results suggest that magnetotactic bacteria are present and provide a source of ultrafine-grained magnetite. ARM plot is calibrated vs. freeze-dried magnetic bacteria (top, open circles) and highly interacting single-domain chiton magnetite (lower, open circles).

netization. As discussed earlier, evidence exists to suggest that the Queensland Plateau has had in the past, and is presently experiencing, rapid fluid flow through the platform, and has had a much more dramatic subsidence history than the Bahamas. The Bahamas have undergone a much slower subsidence, but have also experienced considerable internal fluid exchange, as evidenced by the pervasive dolomitization in the shallow subsurface. The difference in magnetization must thus depend, in part, on the diagenetic changes experienced through, or related to, platform subsidence. With the data presently available, this still remains mostly speculation. 


\section{COMPACTION - LITHIFICATION}

From Schlanger and Douglas (1974)

OOZE

STAGE

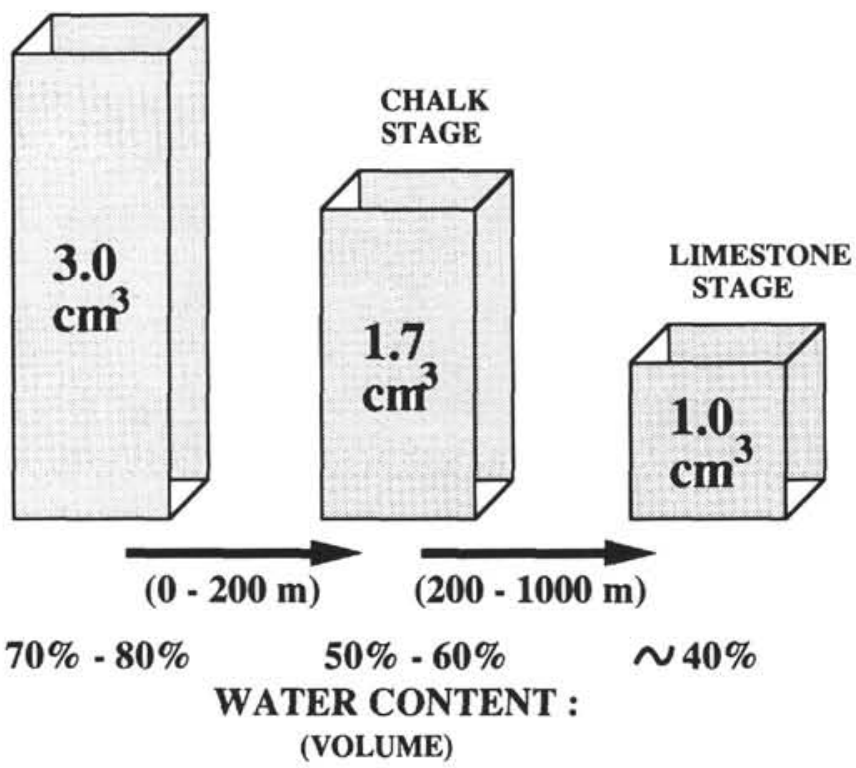

Figure 7. Summary diagram showing the compaction/lithification influence on pelagic limestones. Volume reduction and cementation likely play an important role in post-depositional changes in magnetization. Redrawn from Schlanger and Douglas (1974).

\section{CONCLUSIONS}

Rock-magnetic studies conducted on pure carbonates from the Queensland Plateau provide a much improved data base for the magnetization of Cenozoic carbonates. Comparison of these data with rock-magnetic data from the Bahamas platforms provides a first-order constraint on the source, alteration, and differences in preservation style within the subsurface of carbonate platforms. The tentative conclusion reached here is that carbonate magnetization and its preservation are highly variable on a site-to-site basis and probably are a function of regional platform geohistory and diagenesis. In the case of Sites 811 through 814 on the Queensland Plateau, the author proposes that remanence destruction in the neritic facies was related to the conditions operating within the platform prior to subsidence and that the transition to bathyal conditions has improved the preservation potential of ultrafine-grained magnetic crystals, probably of biogenic origin.

\section{ACKNOWLEDGMENTS}

The Paleomagnetic Laboratory at the University of Miami was established through grants from the National Science Foundation and the W.H. Keck Foundation. Support through NSF Grants EAR-9005354, EAR-8817060, and an NSF REU supplement contributed to the Bahamian rock-magnetic data discussed here. J.L. Kirschvink generously allowed access to his rock-magnetic facilities at Caltech. G.M. Grammer helped with a review of this manuscript. Mike Jackson and one anonymous reviewer are thanked for constructive comments, Rick Sarg is acknowledged for his editorial assistance. This is a contribution from the Rosenstiel School of Marine and Atmospheric Science.

\section{REFERENCES ${ }^{*}$}

Aïssaoui, D.M., McNeill, D.F., and Kirschvink, J.L., 1990. Magnetostratigraphic dating of shallow-water carbonates from Mururoa atoll, French Polynesia: implications for global eustasy. Earth Planet. Sci. Lett., 97:102-112.

Butler, R.F., and Banerjee, S.K., 1975. Theoretical single-domain grain-size range in magnetite and titanomagnetite. J. Geophys. Res., 80:4049-4058.

Chang, S.-B.R., and Kirschvink, J.L., 1985. Possible biogenic magnetite fossils from the Miocene marine clay of Crete. In Kirschvink, J.L., Jones, D.S., and MacFadden, B.J. (Eds.), Magnetite Biomineralization and Magnetoreception in Organisms: New York (Plenum), 647-669.

Chang, S.-B.R., Stolz, J.F., and Kirschvink, J.L., 1987. Biogenic magnetite as a primary remanence carrier in limestone deposits. Phys. Earth Planet. Inter., 46:289-303.

Cisowski, S., 1981. Interacting vs. non-interacting single domain behavior in natural and synthetic samples. Phys. Earth Planet. Inter., 26:56-62.

Fuller, M., Goree, W.S., and Goodman, W.L., 1985. An introduction to the use of SQUID magnetometers in biomagnetism. In Kirschvink, J.L., Jones, D.S., and MacFadden, B.J. (Eds.), Magnetite Biomineralization and Magnetoreception in Organisms: New York (Plenum), 104-151.

Kirschvink, J.L., 1983. Biogenic ferrimagnetism: a new biomagnetism. In Williamson, S.J., Romani, G.L., Kaufman, L., and Modena, I. (Eds.), Biomagnetism: New York (Plenum), 472-492.

Kirschvink, J.L., and Chang, S.R., 1984. Ultrafine-grained magnetite in deepsea sediments: possible bacterial magnetofossils. Geology, 12:559-562.

Leslie, B.W., Hammond, D.E., Berelson, W.M., and Lund, S.P., 1990. Diagenesis in anoxic sediments from the California Continental Borderland and its influence on iron, sulfur, and magnetite behavior. J. Geophys. Res., 95:4453-4470.

Lowrie, W., and Fuller, M., 1971. On the alternating field demagnetization characteristics of multidomain thermoremanent magnetization in magnetite. J. Geophys. Res., 76:6339-6349.

McNeill, D.F., 1989. Magnetostratigraphic dating and magnetization of Cenozoic platform carbonates from the Bahamas [Ph.D. dissert.]. Univ. of Miami, Coral Gables, FL.

, 1990. Biogenic magnetite from surface Holocene carbonate sediments, Great Bahama Bank. J. Geophys. Res., 95:4363-4371.

McNeill, D.F., Ginsburg, R.N., Chang, S.-B.R., and Kirschvink, J.L., 1988. Magnetostratigraphic dating of shallow-water carbonates from San Salvador, Bahamas. Geology, 16:8-12.

McNeill, D.F., and Kirschvink, J.L., in press. Early dolomitization of platform carbonates and the preservation of magnetic polarity. J. Geophys. Res.

McNeill, D.F., Paschke, C.A., Kirschvink, J.L., Sauer, D., and Diaz Ricci, J.C., 1991. Implications for the nature and timing of magnetization in shallowwater carbonates: ARM test results. Eos, 72:142.

Schlanger, S.O., and Douglas, R.G., 1974. The pelagic ooze-chalk-limestone transition and its implication for marine stratigraphy. In Hsü, K.J., and Jenkyns, H.C. (Eds.), Pelagic Sediments: On Land and Under the Sea. Spec. Publ. Int. Assoc. Sedimentol., 1:117-148.

Shipboard Scientific Party, 1991. Site 812. In Davies, P.J., McKenzie, J.A., Palmer-Julson, A., et al., Proc. ODP, Init. Repts., 133 (Pt. 1): College Station, TX (Ocean Drilling Program), 135-176.

, 1991. Site 813. In Davies, P.J., McKenzie, J.A., Palmer-Julson, A. et al., Proc. ODP, Init. Repts., 133 (Pt. 1): College Station, TX (Ocean Drilling Program), 177-202.

1991. Site 814. In Davies, P.J., McKenzie, J.A., Palmer-Julson, A., et al., Proc. ODP, Init. Repts., 133 (Pt. 1): College Station, TX (Ocean Drilling Program), 203-242.

Stolz, J.F., Chang, S.-B.R., and Kirschvink, J.L., 1986. Magnetotactic bacteria and single-domain magnetite in hemipelagic sediments. Nature, $321: 849-851$.

\footnotetext{
Abbreviations for names of organizations and publication titles in ODP reference lists follow the style given in Chemical Abstracts Service Source Index (published by American Chemical Society).
}

Date of initial receipt: 24 July 1992

Date of acceptance: 12 February 1993

Ms 133SR-284 